advantage of the method is the broad reactivity of the MBTH reagent, and therefore one has to be particularly careful with the control incubations.

1. Sowicki, E. et al. Anal. Chem. 33 (1961) 1, 93. 2. Sawicki, E. et al. Anal. Chem. 33 (1961) 11, 1574.

3. Fog, J. and Jellum, E. Nature 195 (1962) 490.

\section{The Degradation of Na-alginate by Enzymes from Alginovibrio aquatilis}

\author{
Kjell E. Eimhjellen, \\ Per A. Rosness and Eva Hegge
}

Department of Biochemistry, The Technical University of Norway, Trondheim, Norway

The depolymerization of polyuronic acids by enzymes from various sources seems to involve in most cases a special hydrolysis mechanism, called transelimination, the first products being 4,5-unsaturated uronides ${ }^{1-3}$.

The degradation of Na-alginate (Diganat from Smith \& Zoon, Bergen, Norway) by Alginovibrio aquatilis Meland ${ }^{4}$ has been studied, and the results indicate that at least two enzymes, or sets of enzymes, are needed for the complete hydrolysis of alginate to the compounds being oxidized by the bacterium.

An extracellular enzyme (alginase) produced during growth on Na-alginate and obtained in purified form, hydrolyzed alginate to a mixture of oligouronides, which were isolated as their Ba-salts insoluble in $50 \%$ ethanol. The products had the spectrum typical for $a, \beta$ unsaturated acids, and by paper chromatography, this mixture could be separated into 5 different compounds or groups of compounds. Incubation of the isolated mixture of oligouronides with alginase gave no further degradation.

The rapid decrease in viscosity of the alginate solution relative to the increase in reducing power, absorption at $232 \mathrm{~m} \mu$ and the amount of $\beta$-formyl-pyruvate forming material are evidence for alginase being an endo-acting enzyme.
Incubation of a mixture of oligouronides or oligouronides purified by paper chromatography, with crude cell-free extracts of the bacteria (grown on Na-alginate as substrate) caused a $1-3$ fold increase in compounds giving $\beta$-formyl-pyruvate by periodate oxidation. The results indicate that the bacterium contains a new enzyme, which completes the hydrolysis of the oligouronides formed from alginate by the action of alginase.

Paper chromatography of the final products, isolated by Sephadex-G 25 filtration, revealed compounds which behaved like 5-keto-4.deoxyuronic or 2-keto-3-deoxy gluconic acid. The reaction mechanism of the hydrolysis of the oligouronides by the intracellular enzyme thus appears to be identical to that of the reaction catalyzed by alginase.

Some results connected to the optimal conditions for the production of alginase will be discussed. Addition of $\mathrm{Ca}^{2}+$ to the medium, and particularly a lowering of the growth temperature had a significant effect on the yield of alginase. Growth of $A$. aquatilis at $2-4^{\circ} \mathrm{C}$ increased the yield $10-50$ times compared to the level of alginase assayed in cultures at $25^{\circ} \mathrm{C}$.

This work was supported by a research grant from The Royal Norwegian Council for Industrial and Scientific Research.

1. Linker, A., Hoffmann, P., Meyer, K., Sampson, P. and Korn, E. J. Biol. Chem. 235 (1960) 3061.

2. Nagel, C. W. and Vaughn, R. H. Arch. Biochem. Biophys. 94 (1961) 328.

3. Preiss, J. and Ashwell, G. J. Biol. Chem. 237 (1962) 309.

4. Meland, S. M. Nytt Magasin for Botanikk 10 (1962) 53.

\section{Relationships of Enzymology to Cancer}

\author{
William Richard Douglas \\ Finsen Institute, Central Laboratory, \\ Copenhagen, Denmark
}

Review of enzymes involved in the neoplastic processes of cancer and their role in diagnosis, prognosis, therapy, and definition 
of generalized disease embracing carcinoma, leukemia, lymphosarcoma and Hodgkin's disease. All enzymes are discussed under the newly accepted terminology and classification of the Commission on Enzymes of the International Union of Biochemistry with the prinoiple behavior of these enzyme activities referred to as oxidoreductases, transferases, hydrolases, lyases, isomerases and ligases. Evidence is offered to support the belief that the elevated amount of lactate dehydrogenase activities are uncharacteristic of the malignant cell itself and probably are reflections of its rapid growth rate as well as more active metabolism. Also, summarizing the numerous reports in the literature on this enzyme, there is much data to indicate that the clinical chemist will soon supply the cancer diagnostician with the cellular source from which originating. Isocitrate dehydrogenase can be an asset when it is noted to have a marked rise in the serum accompanying the enlargement of the liver, which would be consistent with rapid metastatic tumor growth in the liver during the terminal period of the patients life. The catechol oxidase reaction provides a new approach to the diagnosis of malignancy in pigment-cell neoplasms, such as functional nevi versus malignant melanoma, and to the differentiation of amelanotic malignant melanoma from other highly undifferentiated malignant lesions which it simulates, such as fibrosarcoma, lymphoma, and squamous-cell carcinoma. The non-specific aspartate aminotransferase and alanine aminotransferase as currently viewed appear to be measures of cell damage rather than cell function and can be regarded as normal intracellular enzymes. Ribonuclease, although only indirectly related to cancer, has been shown to exist as several isoenzymes differing either in $\mathrm{pH}$ optima, their tissue origin or their nucleotide end-products. Stress in recent years on acid phosphatase activity has been not only to detect the occurrence of metastases in prostatic disease, but to assess the progress of therapy in such cases. The relationship of over thirty peptide hydrolases has positive value in cancer involving pancreas, small intestine, gastric mucosa and gastric muscle, but need further clarification. No attempt is made to depict clinical enzymology as the singularly significant approach to cancer, but to point out correlations which are illustrative of the larger problems to face in cancer definition.

\section{The Biosynthesis of Palmitylcarni- tine in Cell Subfractions

\author{
J o n $B$ r e m e r *
}

Institute of Clinical Biochemistry, Rikshospitalet, University of Oslo, Oslo, Norway

Carnitine is known to stimulate the oxidation of long chain fatty acids in tissue homogenates ${ }^{1}$. Recently we have shown that palmitylcarnitine and other fatty acid esters of carnitine are metabolized by mitochondria from several tissues of the rat ${ }^{2}$, indicating that these esters are intermediates in the carnitine stimulated oxidation of fatty acids.

Table 1. The biosynthesis of palmitylcarnitine by rat liver microsomes. Rat liver was homogenized in 10 volumes of $10 \%$ sucrose containing $10^{-2} \mathrm{M}$ glycylglycine buffer, $\mathrm{pH}$ 7.5. Cell debris, nuclei and mitochondria were removed by centrifugation at $20000 \times g$ for $10 \mathrm{~min}$. The microsomes were isolated from the supernatant by centrifugation at $150000 \times g$ for $60 \mathrm{~min}$.

The complete reaction mixture contained in a total volume of $1 \mathrm{ml}$ : Microsomes corresponding to $70 \mathrm{mg}$ fresh liver in $0.5 \mathrm{ml}$ of homogenizing medium; $0.5 \mu$ mole of palmitate in complex with $10 \mathrm{mg}$ of crystalline bovine albumin; $10 \mu$ moles of ATP; $0.1 \mu$ mole of CoA; $5 \mu$ moles of magnesium chloride; $10 \mu$ moles of GSH; $25 \mu$ moles of sodium fluoride; and $0.27 \mu$ mole of L-carnitine-1 ${ }^{14} \mathrm{C}=37000$ counts $/ \mathrm{min}$. The incubation was performed for $15 \mathrm{~min}$ at $30^{\circ}$. The formation of palmitylcarnitine was assayed as butanol-extractable radioactivity with a method previously described ${ }^{3}$. Palmitylcarnitine is quantitatively extracted by butanol, while free carnitine is not extracted.

Factor omitted from the reaction mixture

Counts/min extracted with butanol

\begin{tabular}{lrr} 
None & 15500 & 15400 \\
ATP & 50 & 20 \\
Co A & 520 & 460 \\
Albumin palmitate & 3000 & 2900 \\
MgCl $_{2}$ & 13100 & 12950 \\
$\mathrm{NaF}$ & 13100 & 12900 \\
GSH & 14900 & 14200 \\
Microsomes & 0 & \\
\hline
\end{tabular}

* Fellow of the Norwegian Cancer Society, Oslo, Norway.

Acta Chem. Scand. 17 (1963) No. 3 